\title{
PENGARUH COOPERATIVE LEARNING (TPS) DAN KETERAMPILAN BERPIKIR KRITIS TERHADAP HASIL BELAJAR IPA SISWA
}

\author{
Taufik \\ Fakultas Keguruan dan Ilmu Pendidikan Universitas Mulawarman \\ taufikmadrinitas@gmail.com
}

\begin{abstract}
Abstrak
Penelitian ini bertujuan mengetahui: (1) Perbedaan hasil belajar IPA sebelum dan sesudah penerapan model cooperative learning tipe think pair share, (2) Perbedaan hasil belajar IPA siswa yang menggunakan model cooperative learning tipe think pair share dan model pembelajaran konvensional, (3) Perbedaan hasil belajar IPA siswa yang memiliki keterampilan berpikir kritis tinggi dan keterampilan berpikir kritis rendah pada penerapan model cooperative learning tipe think pair share, (4) Interaksi antara penerapan model pembelajaran cooperative learning tipe think pair share dan keterampilan berpikir kritis siswa terhadap hasil belajar IPA siswa. Pendekatan dalam penelitian menggunakan pendekatan kuantitatif metode quasi eksperimen. Pengumpulan data dilakukan melalui angket dan post test. Sampel penelitian dipilih dengan teknik purposive sampling. Data dianalisis dengan menggunakan uji paired sample t-test dan two way Anova. Hasil akhir penelitian dapat disimpulkan adanya pengaruh penerapan model cooperative learning tipe think pair share dan keterampilan berpikir kritis siswa terhadap hasil belajar IPA siswa.
\end{abstract}

Kata Kunci: Cooperative Learning (TPS), Keterampilan Berpikir Kritis, Hasil Belajar IPA

Abstract

This study aims to determine: (1) The differences in science learning outcomes before and after the application of the think pair share cooperative learning model, (2) The differences in science learning outcomes using the cooperative learning model type think pair share and conventional learning models, (3) Differences in science learning outcomes who have high critical thinking skills and low critical thinking skills in the application of the cooperative learning type think pair share model, (4) The interaction between the application of the think pair share cooperative learning model and students' critical thinking skills towards the science learning outcomes. The approach in research uses a quantitative approach to the quasi-experimental method. Data collection was done through questionnaires and post tests. The research sample was selected by purposive sampling technique. Data were analyzed using paired sample t-test and two way Anova. The final results of the study can be concluded that there is an effect of the application of the cooperative learning type think pair share model and critical thinking skills of students on student learning outcomes in science.

Keywords: Cooperative Learning (TPS), Critical Thinking Skills, Science Learning Outcomes

\section{PENDAHULUAN}

Pembangunan dan pemberdayaan bidang pendidikan di Indonesia mendapat perhatian yang sungguh-sungguh dari pemerintah. Penekanan yang terpenting dalam pelaksanaan pendidikan formal adalah proses belajar dan mengajar. Proses belajar dan mengajar sebagai salah satu upaya melaksanakan pembangunan Nasional merupakan tanggung jawab yang berat khususnya bagi pelaksana di bidang pendidikan yaitu guru di sekolah. Guru mempunyai peranan yang sangat penting sehubungan dengan tugasnya sebagai perencana dan pelaksana sekaligus mengevaluasi kegiatan belajar mengajar. Setiap guru yang akan mengajar senantiasa dihadapkan pada pemilihan model. Kelebihan suatu model pembelajaran terletak pada ketepatan memilih sesuai dengan tujuan pembelajaran. Tujuan utama yang ingin dicapai dalam kegiatan pembelajaran adalah hasil belajar. Hasil belajar digunakan untuk mengetahui sebatas mana siswa dapat memahami serta mengerti materi tersebut. Nilai hasil belajar menurut Gagne (dalam Dimyati dan Mudjiono 2015: 11-12), "dapat dikelompokkan dalam lima kategori, meliputi informasi verbal, keterampilan intelektual, strategi kognitif, keterampilan motorik, dan sikap". Kondisi hasil belajar internal dipengaruhi banyak faktor diantaranya, minat, motivasi, respon belajar, dan keterampilan berpikir kritis.

Keterampilan berpikir kritis menjadi salah satu faktor yang menentukan hasil belajar siswa. Siswa yang mempunyai kemampuan berpikir kritis, akan selalu tampak dalam proses menyelesaikan masalah belajarnya, dimana siswa akan selalu mencari kejelasan pada setiap masalah, berpikir terbuka, berpikir secara integral, dan berpikir objektif. Kemudian, Fitriadi (2016, hlm. 253) menjelaskan bahwa berpikir yang fokus atau berorientasi bukti dibandingkan 
emosi atau bias pribadi dapat membantu siswa dalam meningkatkan kemampuan kognitifnya. Pembelajaran dengan pelibatan keterampilan berpikir kritis harus diajarkan sejak usia dini. Usia dini merupakan masa menanamkan karakter pada anak sehingga tumbuh kebiasaan yang baik. Kemampuan berpikir kritis melalui enam aspek perkembangan anak usia dini perlu ditumbuhkan dan dibiasakan tanpa anak sadari.

Pada kurikulum 2013, salah satu kompetensi yang harus dikuasai siswa pada pembelajaran sains adalah keterampilan berpikir kritis (Kemendikbud, 2016). Kegiatan belajar IPA adalah pembelajaran yang melibatkan keaktifan anak secara penuh, karena dalam pembelajaran IPA terdapat pengetahuan yang sistematis dan disusun dengan menghubungkan gejala-gejala alam yang bersifat kebendaan dan didasarkan pada hasil pengamatan dan penyelidikan, maka diperlukan kelibatan anak secara utuh dalam pembelajaran tersebut. Dalam hal ini, di perlukan kreatifitas guru dalam kegiatan pembelajaran agar tujuan pembelajaran IPA tercapai dengan baik. Maka dari itu seorang guru dituntut menggunakan model pembelajaran yang tepat, diantaranya dengan model Cooperatif Learning pada saat proses pembelajaran, karena akan memberikan kesempatan pada siswa untuk aktif turut serta mencari sumber-sumber yang dapat dimanfaatkan sehingga meningkatkan aktifitas belajar dan wawasan siswa.

Riyanto (2012: 265) berpendapat bahwa cooperatif learning adalah pendekatan pembelajaran yang berfokus pada penggunaan kelompok kecil siswa untuk bekerja sama dalam memaksimalkan kondisi belajar untuk mencapai tujuan. Falsafah yang menjadi dasar dalam cooperative learning adalah manusia sebagai mahluk sosial, gotong royong, dan kerja sama merupakan kebutuhan penting bagi kehidupan manusia. Tujuan pokok dari model cooperative learning diantaranya hasil belajar akademik, penerimaan terhadap perbedaan individu, dan pengembangan keterampilan sosial. Keunggulan cooperative learning diantaranya dapat meningkatkan kualitas kepribadian anak, menumbuhkan semangat persatuan yang positif dan konstruktif, serta menanamkan rasa persatuan dan solidaritas yang tinggi.
Salah satu model cooperative learning yang dapat di terapkan adalah cooperative learning tipe think pair share (TPS). Think pair share (TPS) adalah salah satu alternatif model cooperative learning agar pembelajaran mampu membuat siswa lebih aktif serta dapat mengungkapkan pikiran dan gagasannya serta adanya kerja sama antar siswa, yaitu dengan menggunakan sharing dalam proses kegiatan belajar. Cooperative learning tipe think phare share (TPS) diterapkan untuk meningkatkan pembelajaran kolaboratif dan mendorong kepentingan serta keuntungan sinergi tersebut. Cooperative learning tipe think pair share (TPS) dapat meningkatkan kemampuan siswa dalam mengingat suatu informasi dan seorang siswa juga dapat belajar dari siswa lain serta saling menyampaikan idenya untuk didiskusikan sebelum disampaikan di depan kelas.

Penggunaan model cooperative learning tipe think pair share (TPS) pada kegiatan belajar mengajar IPA siswa kelas VIII SMP Negeri 4 Samarinda diharapkan mampu meningkatkan keterampilan berpikir kritis siswa dan hasil belajar IPA siswa. Dengan demikian ada keterkaitan antara model pembelajaran cooperative learning tipe think pair share (TPS), keterampilan berpikir kritis siswa, dan hasil belajar IPA siswa.

Berdasarkan uraian di atas maka penulis terdorong untuk melakukan penelitian tentang "Pengaruh model cooperative learning tipe think pair share (TPS) dan keterampilan berpikir kritis siswa terhadap hasil belajar IPA siswa kelas VIII unggulan IT SMP Negeri 4 Samarinda (Konsep getaran, gelombang, dan bunyi)".

\section{METODE}

Penelitian yang digunakan untuk mencari pengaruh perlakuan terhadap tertentu terhadap yang lain dalam kondisi yang terkendalikan. Penelitian eksperimental semu adalah suatu desain penelitian yang memiliki kelompok kontrol tetapi tidak dapat berfungsi sepenuhnya untuk mengontrol variabel-variabel dari luar yang mempengaruhi pelaksanaan eksperimen" (Sugiono, 2013: 72). Desain penelitian ini menggunakan nonquivalent control group design, dimana ada dua kelompok kelas yang dilakukan penelitian. Dua kelompok kelas tersebut yaitu 
kelompok kelas eksperimen yang akan memperoleh pengajaran dengan model cooperative learning tipe think pair share dan kelompok kelas kontrol yang akan mendapat pembelajaran dengan model konvensional. Penelitian dilaksanakan di SMP Negeri 4 di Jalan Ir. H. Juanda RT. 17 No.14, Air Putih, Kec. Samarinda Ulu, Kota Samarinda pada pada bulan Maret sampai dengan bulan Mei 2020. Populasi dalam penelitian ini adalah siswa kelas VIII SMP Negeri 4 Samarinda tahun pembelajaran 2019/2020 yang terdiri atas 10 kelas dan berjumlah 322 siswa.

Teknik yang dipakai dalam pengambilan sampel ini adalah purposive sampling. Purposive sampling adalah salah satu teknik sampling non random sampling dimana peneliti menentukan pengambilan sampel dengan cara menetapkan ciri-ciri khusus yang sesuai dengan tujuan penelitian sehingga diharapkan dapat menjawab permasalahan penelitian. Teknik penentuan sampel ini dengan pertimbangan tertentu yang disarankan oleh dosen pembimbing peneliti dan guru IPA. Salah satu pertimbangan pengambilan sampel dengan teknik ini digunakan karena populasi dipandang homogeny yang hanya mengandung satu ciri sehingga populasi memiliki peluang yang sama untuk menjadi sampel.

Sampel dari penelitian ini diambil dari dua kelas yang dipandang memiliki homogeny yaitu kelas VIII.1 (sebagai kelas eksprimen) dan kelas VIII.2 (sebagai kelas kontrol). Kelas VIII.1 dan kelas VIII.2 merupakan kelas IT unggulan dengan fasilitas khusus diantaranya terdapat wifi, ac, LCD, dispenser, dan ruangan IT khusus mandiri. Penelitian ini dilaksanakan dengan 7 kali pertemuan baik untuk kelas eksperimen maupun kelas kontrol, dan tiap-tiap pertemuan dilaksanakan sesuai dengan perubahan kompetensi yang di capai, berdasarkan perencanaan yang telah di desain sebelumnya.

\section{HASIL DAN PEMBAHASAN Hasil}

Hipotesis pertama, terdapat perbedaan hasil belajar IPA siswa kelas VIII (Unggulan IT) SMP Negeri 4 Samarinda sebelum dan sesudah penerapan model cooperative learning tipe think pair share (TPS). Pengujian hipotesis pertama ini dengan cara melakukan uji statistik data nilai pre test dan post test pada kelas eksperimen. Berdasarkan output paired samples test, diketahui nilai Sig. (2-tailed) adalah sebesar 0,000. Oleh karena $0,000<0,05$, maka $\mathrm{H}_{0}$ ditolak dan $\mathrm{H}_{\mathrm{a}}$ diterima. Sehingga dapat disimpulkan bahwa ada perbedaan rata-rata antara hasil belajar pre test dan post test yang artinya bahwa ada pengaruh penerapan model cooperative learning tipe think pair share (TPS) terhadap hasil belajar IPA siswa.

Hipotesis kedua, terdapat perbedaan hasil belajar IPA siswa kelas VIII (Unggulan IT) SMP Negeri 4 Samarinda yang menggunakan model cooperative learning tipe think pair share (TPS) dan model pembelajaran konvensional. Pengujian hipotesis kedua ini dengan cara melakukan uji statistik data nilai post test pada kelas eksperimen dan kelas kontrol. Berdasarkan output anova, diketahui nilai Sig. variabel model pembelajaran adalah sebesar 0,000. Oleh karena 0,000<0,05, maka $\mathrm{H}_{0}$ ditolak dan $\mathrm{H}_{\mathrm{a}}$ diterima. Sehingga dapat disimpulkan bahwa ada perbedaan hasil belajar IPA siswa kelas VIII (unggulan IT) SMP Negeri 4 Samarinda yang menggunakan model cooperative learning tipe think pair share (TPS) dan model pembelajaran konvensional.

Hipotesis ketiga, terdapat perbedaan hasil belajar IPA siswa kelas VIII (Unggulan IT) SMP Negeri 4 Samarinda yang memiliki keterampilan berpikir kritis tinggi dan yang memiliki keterampilan berpikir kritis rendah. Pengujian hipotesis ketiga ini dengan cara melakukan uji statistik data nilai post test pada tingkat keterampilan berpikir kritis dan keterampilan berpikir kritis rendah siswa. Berdasarkan tabel output anova, diketahui nilai Sig. variabel keterampilan berpikir kritis adalah sebesar 0,000. Oleh karena $0,000<0,05$, maka $\mathrm{H}_{0}$ ditolak dan $\mathrm{H}_{\mathrm{a}}$ diterima. Sehingga dapat disimpulkan bahwa ada perbedaan hasil belajar IPA siswa kelas VIII (unggulan IT) SMP Negeri 4 Samarinda yang memiliki keterampilan berpikir kritis tinggi dan yang memiliki keterampilan berpikir kritis rendah.

Hipotesis keempat, terdapat interaksi antara penerapan model pembelajaran cooperative learning tipe think pair share (TPS) dan keterampilan berpikir kritis terhadap hasil belajar IPA siswa kelas VIII unggulan IT SMP Negeri 4 Samarinda. Berdasarkan tabel output 
two way anova, diketahui nilai Sig. model pembelajaran dan interaksinya dengan variabel keterampilan berpikir kritis secara bersama-sama terhadap hasil belajar IPA siswa adalah sebesar 0,901. Oleh karena $0,901>0,05$, maka $\mathrm{H}_{0}$ ditolak dan $\mathrm{H}_{\mathrm{a}}$ diterima. Sehingga dapat disimpulkan bahwa tidak terdapat interaksi antara penerapan model pembelajaran cooperative learning tipe think pair share (TPS) dan keterampilan berpikir kritis terhadap hasil belajar IPA siswa kelas VIII Unggulan IT SMP Negeri 4 Samarinda.

\section{Pembahasan}

Terdapat perbedaan rata-rata antara hasil belajar pre test dan post test yang artinya bahwa ada pengaruh penerapan model cooperative learning tipe think pair share (TPS) terhadap hasil belajar IPA siswa. Hal ini berdasarkan hasil uji paired samples test diperoleh nilai Sig. (2tailed) sebesar 0,000. Oleh karena 0,000 $<0,05$, maka $\mathrm{H}_{0}$ ditolak dan $\mathrm{H}_{\mathrm{a}}$ diterima. Hal ini didukung dengan perolehan rata-rata post test kelas eksperimen yang diterapkan model cooperative learning tipe think pair share (TPS) sebesar 90,75, lebih tinggi dari rata-rata pre test sebesar 66,63 . Hal ini menunjukkan bahwa nilai post test kelas eksperimen setelah penerapan model cooperative learning tipe think pair share (TPS) lebih tinggi dari nilai pre test sebelum penerapan model cooperative learning tipe think pair share (TPS). Penerapan model cooperative learning tipe think pair share (TPS) berdampak positif terhadap pencapaian hasil belajar IPA siswa. Cooperative learning tipe think pair share dapat memperbaiki rasa percaya diri dan semua siswa diberi kesempatan berpartisipasi dalam kelas.

Terdapat perbedaan hasil belajar IPA siswa kelas VIII (unggulan IT) SMP Negeri 4 Samarinda yang menggunakan model cooperative learning tipe think pair share (TPS) dan model pembelajaran konvensional. Hal ini berdasarkan hasil uji two way anova diperoleh nilai Sig. sebesar 0,000. Oleh karena $0,000<$ 0,05 , maka $\mathrm{H}_{0}$ ditolak dan $\mathrm{H}_{\mathrm{a}}$ diterima. Hal ini didukung dengan perolehan rata-rata hasil belajar IPA kelompok siswa yang diajar dengan model cooperative learning tipe think pair share sebesar 90,75 , sedangkan rata-rata hasil belajar IPA kelompok siswa yang diajar dengan model konvensional. Hal ini menunjukkan bahwa nilai hasil belajar yang diajar dengan model cooperative learning tipe think pair share (TPS) lebih tinggi dari nilai hasil belajar yang diajar dengan model konvensional. Penerapan model cooperative learning tipe think pair share (TPS) lebih efektif daripada model pembelajaran konvensional dalam pencapaian hasil belajar siswa. Kelas eksperimen yang diterapkan model pembelajaran cooperative learning tipe think pair share (TPS) memberikan siswa kesempatan untuk bekerja sendiri serta bekerja sama dengan orang lain, sengaja dirancang untuk mempengaruhi pola interaksi siswa. Kelas kontrol yang diajar menggunakan model pembelajaran konvensional lebih menekankan pada penyampaian materi secara verbal. Hasil belajar kelas eksperimen diajar yang menggunakan model cooperative learning tipe think pair share (TPS) yang lebih tinggi menunjukkan model ini lebih efektif dalam merangsang siswa untuk menemukan dan mengembangkan keterampilan berpikirnya dalam pemecahan masalah.

Terdapat perbedaan hasil belajar IPA siswa kelas VIII (unggulan IT) yang memiliki keterampilan berpikir kritis tinggi dan yang memiliki keterampilan berpikir kritis rendah. Dengan demikian terdapat pengaruh keterampilan berpikir kritis siswa terhadap hasil belajar IPA siswa. Hal ini berdasarkan hasil uji two way anova diperoleh nilai Sig. sebesar 0,000. Oleh karena $0,000<0,05$, maka $\mathrm{H}_{0}$ ditolak dan $\mathrm{H}_{\mathrm{a}}$ diterima. Hasil belajar IPA siswa yang memiliki keterampilan berpikir kritis tinggi signifikan lebih tinggi dibandingkan dengan siswa yang memiliki keterampilan berpikir kritis rendah. Dengan demikian siswa dengan keterampilan berpikir kritis tinggi lebih cocok diterapkan model pembelajaran cooperative learning tipe think pair share. Cooperative learning tipe think pair share (TPS) sangat tepat diterapkan pada siswa yang memiliki keterampilan berpikir kritis tinggi, karena siswa dengan keterampilan berpikir kritis tinggi ini mampu memperoleh strategi yang logis, rasional dan abstrak. Keterampilan berpikir kritis tinggi akan menjadi faktor penentu dalam pelaksanaan pembelajaran cooperative learning tipe think pair share (TPS). Siswa dengan keterampilan berpikir kritis rendah, hasil 
belajarnya lebih rendah dibandingkan siswa yang memiliki keterampilan berpikir kritis tinggi, disebabkan pola penalaran dan pelibatan untuk perumusan pencarian permasalahan yang tidak merata, di dominasi siswa yang masih aktif, dan kurangnya keterampilan berbagi peran dalam pembelajaran.

Tidak terdapat interaksi antara penerapan model pembelajaran cooperative learning tipe think pair share (TPS) dan keterampilan berpikir kritis secara bersama-sama terhadap hasil belajar IPA siswa kelas VIII unggulan IT SMP Negeri 4 Samarinda. Hal ini berdasarkan hasil uji two way anova diperoleh nilai Sig. sebesar 0,901. Oleh karena $0,901<0,05$, maka $\mathrm{H}_{0}$ diterima dan $\mathrm{H}_{\mathrm{a}}$ ditolak. Tidak adanya interaksi antara penerapan model pembelajaran cooperative learning tipe think pair share (TPS) dan keterampilan berpikir kritis dapat disebabkan karena selama ini siswa terbiasa dengan pembelajaran yang berpusat pada guru. Kendati demikian, model pembelajaran cooperative learning tipe think pair share (TPS) yang digunakan dalam penelitian ini, baik secara teoritis maupun praktis dapat menjadi sarana untuk mengembangkan kegiatan berpikir kritis melalui kegiatan pembelajaran. Pengamatan peneliti selama penelitian, menemukan kurangnya waktu dan rumitnya persiapan model pembelajaran cooperative learning tipe think pair share (TPS) dan keterampilan bepikir kritis menyebabkan adanya kecendurungan tenaga pendidik untuk tidak menerapkan keduanya. Padahal dalam kurikulum 2013, siswa dituntut untuk mengembangkan keterampilan berpikir kritis nya melalui kegiatan pembelajaran yang mendukung pengembangan keterampilan berpikir kritis tersebut. Siswa yang memiliki keterampilan berpikir kritis akan lebih mudah dalam penggabungan informasi dan gagasan baru kedalam satu sudut pandang, konsep dan asumsi yang dimiliki siswa akan dapat menafsirkan data dan menyimpulkan informasi yang di peroleh. Guru mempunyai peranan yang sangat penting dalam pemilihan model pembelajaran. Pemilihan model pembelajaran yang tepat adalah yang sesuai tujuan pembelajaran. Semakin tepat model pembelajaran yang digunakan maka diharapkan semakin efektif pula pencapaian tujuan pembelajaran. Dengan demikian, fungsi-fungsi model pembelajaran tidak dapat diabaikan karena model pembelajaran tersebut turut menentukan berhasil tidaknya suatu proses belajar mengajar. Begitu pula sebaliknya, penggunaan model pembelajaran yang tidak sesuai tujuan pembelajaran akan menjadi kendala dalam pencapaian tujuan pembelajaran yang akan dirumuskan. Cukup banyak bahan pelajaran yang terbuang dengan percuma hanya karena pengunaan model pembelajaran semata-mata berdasarkan kehendak guru dan bukan atas dasar kebutuhan siswa. Kegiatan pembelajaran IPA perlu melibatkan keaktifan anak secara penuh, karena dalam pembelajaran IPA terdapat pengetahuan yang sistematis dan disusun dengan menghubungkan gejala-gejala alam yang bersifat kebendaan dan didasarkan pada hasil pengamatan dan penyelidikan. Dengan demikian, faktor internal dan eksternal sangat berpengaruh terhadap hasil belajar IPA. Faktor internal yang berpengaruh terhadap hasil belajar adalah minat belajar siswa. Minat besar pengaruhnya terhadap hasil belajar, karena bila bahan pelajaran yang dipelajari tidak sesuai dengan minat siswa, siswa tidak akan belajar dengan sebaik-baiknya, karena tidak ada daya tarik baginya. Adapun faktor eksternal yang peneliti yakini berpengaruh terhadap hasil belajar IPA siswa adalah model pembelajaran dan media pembelajaran. Hal ini mengingat pembelajaran IPA tidak hanya penyampaikan kumpulan pengetahuan yang berupa fakta-fakta, konsep-konsep, prinsipprinsip atau penyampaian materi abstrak saja, akan tetapi pembelajaran IPA merupakan suatu proses penemuan pengetahuan, pembentukan sikap ilmiah, juga kemampuan untuk menerapkan prinsip-prinsip IPA itu sendiri ke dalam kehidupan sehari-hari. Hal ini berkaitan dengan teknologi pendidikan untuk membantu penggunaan media pembelajaran secara tepat. Faktor lain yang cukup berpengaruh terhadap hasil belajar IPA siswa adalah adanya bimbingan belajar per mata pelajaran yang diterima siswa, baik dari guru mata pelajaran saat akan ujian, atau bimbingan belajar siswa yang diterima luar sekolah. Tambahan bimbingan belajar ini peneliti yakini cukup berpengaruh terhadap hasil belajar IPA siswa, selain model pembelajaran, keterampilan berpikir kritis, minat belajar, dan media pembelajaran. 


\section{KESIMPULAN}

Berdasarkan hasil pengujian hipotesis pada data hasil penelitian yang telah dilakukan, dapat diambil kesimpulan penelitian sebagai berikut:

1. Terdapat perbedaan hasil belajar IPA siswa kelas VIII (unggulan IT) SMP Negeri 4 Samarinda sebelum dan sesudah penerapan model cooperative learning tipe think pair share (TPS).

2. Terdapat perbedaan hasil belajar IPA siswa kelas VIII (unggulan IT) SMP Negeri 4 Samarinda yang menggunakan model cooperative learning tipe think pair share (TPS) dan model pembelajaran konvensional.

3. Terdapat perbedaan hasil belajar IPA siswa kelas VIII (Unggulan IT) SMP Negeri 4 Samarinda yang memiliki keterampilan berpikir kritis tinggi dan yang memiliki keterampilan berpikir kritis rendah.

4. Tidak terdapat interaksi antara penerapan model pembelajaran cooperative learning tipe think pair share (TPS) dan keterampilan berpikir kritis terhadap hasil belajar IPA siswa kelas VIII Unggulan IT SMP Negeri 4 Samarinda.

\section{UCAPAN TERIMA KASIH}

Ucapan terima kasih yang sebesar-besarnya peneliti sampaikan kepada Rektor Universitas Mulawarman, Ketua Program Magister Kependidikan Fakultas Keguruan dan Ilmu Pendidikan Universitas Mulawarman, seluruh dosen Pascasarjana Kependidikan, Prof. Dr. H. Muh. Amir Masruhim, M.Kes selaku Dosen Pembimbing I, dan bapak Dr. Yudo Dwiyono, M. Si selaku Dosen Pembimbing II. Dr. Sudarman, M.Pd., Dr. Azainil, M.Si dan Dr. H. Saraka, M.Pd. selaku dosen penguji. Kepala sekolah, guru, beserta staff tata usaha SMP Negeri 4 Samarinda, dan rekan-rekan mahasiswa Program Magister Kependidikan khususnya jurusan Teknologi Pendidikan angkatan 2015 atas dukungannya sehingga saya dapat menyelesaikan tesis ini. Orang tua saya, H. Asri dan $\mathrm{Hj}$ Aminah, Istri saya Siti Fatimah,S.Si dan Anak saya Arsyad Rasqa Asr yang selama ini telah memberikan dukungan. Serta Teman-teman kerja di program KOTAKU yang selama ini telah banyak memberikan ruang dan waktu untuk saya menyelesaikan penelitian saya.

\section{DAFTAR PUSTAKA}

Abdullah, Ridwan,. 2013. Inovasi Pembelajaran. Jakarta : Bumi Aksara.

Aunurrahman. 2014. Belajar Dan Pembelajaran. Cetakan Kesembilan. Bandung: Alfabeta.

Basuki, Ismat \& Hariyanto. 2014. Asessmen Pembelajaran. Bandung: Remaja Rosdakarya.

Cottrell, Stella. 2015. Critical Thinking Skills, Palgrave Macmillan.

Darsono. 2017. The Influence of Cooperative Learning Model of Think Pair Square with Problem Posing Task on Students" Mathematics Learning Outcome. Advances in Social Science, Education and Humanities Research, volume 173. Universitas Negeri Surabaya, Surabaya, Indonesia.

Dimyati dan Mudjiono. 2015. Belajar Dan Pembelajaran. Cetakan kelima. Jakarta: Rineka Cipta.

Fitriadi, A. (2016). The Correlation between Critical Thinking Skills and Critical Thinking Dispositions of the Fifth Semester Student of English Department in Academic Years 2015/2016. Konferensi Antarabangsa Islam Borneo Ke-9 (KAIB IX), 9(25), 250.

Gull, Farihal. 2015. Effects of Cooperative Learning On Students' Academic Achievement. Journal of Education and Learning Vol. 9 (3) pp. 246-255. University of the Punjab, Lahore, Pakistan.

H. A. R. Tilaar. 2011. Pedagogik Kritis. Jakarta: Bumi Aksara.

Hamdan, Khaleel Ribhi Ahmad. 2017. The Effect of (Think Pair Share) Strategy on the Achievement of Third Grade Student in Sciences in the Educational District of Irbid. Vol.8, No.9, 2017. The Ministry of Education, the educational district of Irbid.

Haseli, Zahra \& Rezaii, Fahimeh. 2013. The Effect of Teaching Critical thinking on Educational Achievement and Test Anxiety among Junior High School Students in Saveh, Iran.

Hidayat, Isnu. 2019. 50 Strategi Pembelajaran Populer. Yogyakarta: DIVA Press 
Huda, Miftahul. 2013. Model-model pembelajaran dan pengajaran. Yogyakarta: Pustaka Pelajar.

Isjoni. 2013. Pembelajaran Kooperatif. Yogyakarta: Pustaka Pelajar.

Jamaris, Martini. 2013. Orientasi baru dalam psikologi pendidikan. Jakarta: Ghalia Indonesia.

Jihad \&Haris. 2012. Evaluasi Pembelajaran. Yogyakarta: Multi Presindo.

Karakoc, Murat. 2016. The Significance of Critical Thinking Ability in terms of Education. International Journal of Humanities and Social Science. Vol. 6, No. 7; July 2016. İstanbul Aydın University Institute of Social Sciences, Turkey.

KBBI. Pengertian Berpikir menurut KBBI. https://kbbi.web.id/pikir. Diakses pada tanggal 10 Desember 2019 pukul 19.00 Wita

Kementerian Pendidikan \& Kebudayaan. 2014. Ilmu Pengetahuan Alam Kelas VIII Semester 2.

Kompasiana, 2013. Mengajarkan Keterampilan Berpikir Kritis Pada SIswa. https://www.kompasiana.com/turmuzi.ah $\mathrm{mad} / 55285113 \mathrm{f} 17 \mathrm{e} 61893 \mathrm{~b} 8 \mathrm{~b} 4581 / \mathrm{mengaj}$ arkan-keterampilan-berpikir-kritis-padasiswa. Di Akses pada tanggal 10 Desember 2019 Pukul 21.00 Wita.

Olga, Dkk. 2016. Critical Thinking and its Importance in Education: Some Reflections.

Pertiwi, Muspratiwi, Tesis, 2017. Keterampilan Berpikir Kritis Pada Pembelajaran IPA Siswa Kelas $V$ Sekolah Dasar (SD). Malang: Universitas Negeri Malang.

Prahl, Kristine. 2017. Best Practices for the Think-Pair-Share Active-Learning Technique. The American Biology Teacher.

Resti, Stefani Nawati Eko, Tesis, 2014. Hubungan motivasi berprestasi siswa dan kemampuan berpikir kritis siswa dengan hasil belajar Ilmu Pengetahuan Sosial (IPS) Siswa. Jakarta: Universitas Negeri Jakarta.
Rifa'i \& Lestari. 2018. The effect of Think Pair Share (TPS) using scientific approach on students' self-confidence and mathematical problem solving. Yogyakarta: Yogyakarta State University.

Riyanto, Yatim. 2012. Paradigma Baru Pembelajaran. Jakarta: Kencana.

Santrok J. W. 2013. Adolescence (Perkembangan Remaja). Jakarta: Erlangga

Seniati, dkk. 2011. Psikologi Eksperimen. Jakarta: Indeks.

Soe'oed, Rahmat, 2017. Mengapa banyak orang pandai tidak kritis, cetakan ketiga, Yogyakarta: Kalika.

Sudarman, Tesis, 2008. pengaruh model pembelajaran berbasis masalah dan kemampuan berpikir kritis terhadap hasil belajar mata pelajaran ekonomi siswa MAN 2 Samarinda (Samarinda: Universitas Mulawarman)

Suharmoko, Tesis, 2015. Pengaruh Model Pembelajaran Kooperative Tipe Artikulasi dan Keterampilan Berpikir Kritis Terhadap Hasil Belajar Al-quran Hadis Kelas VII MTs. Antasari Samarinda. (Samarinda: Universitas Mulawarman)

Sumarmo. 2012. Kemampuan dan Disposisi Berpikir Logis, Kritis, dan Kreatif Matematik, Jurnal Pengajaran MIPA Vol 17 No. 1: 17-33.

Surya, Hendra. 2011. Strategi Jitu Mencapai Kesuksesan Belajar. Jakarta: Gramedia.

Susanto, Ahmad. 2013. Teori Belajar dan Pembelajaran di Sekolah Dasar. Jakarta: Kencana Prenada Media Grup.

Suprijono, Agus. 2012. Cooperative Learning Teori dan Aplikasi Paikem. Yogyakarta: Pustaka Pelajar.

Websiteedukasi.com. Perangkat pembelajaran IPA Kelas $8 \quad$ K13 Revisi 2019. (https://www.websiteedukasi.com/2018/0 2/administrasi-ipa-kelas-8-smpmtsk13.html). Diakses pada tanggal 10 Desember 2019 Pukul 19.00 Wita.

Zubaedi (2012). Desain Pendidikan Karakter. Jakarta: Kencana. 